\title{
Specificities of French community gardens as environmental stewardships
}

\author{
$\underline{\text { Ana Cristina Torres }}^{1,2}, \underline{\text { Sophie Nadot }}^{2}$ and $\underline{\text { Anne-Caroline Prévot }}^{1}$
}

\begin{abstract}
Community-based efforts are essential to address urban social-ecological challenges. Here, we focus on French community gardens. Through participant observation and semistructured interviews, this study seeks to provide empirical evidence on: (1) what motivates volunteer gardeners in French community gardens to undertake this activity, (2) what practices take place in the gardens, and (3) which individual and collective processes are associated with gardeners' experiences in the gardens. Through these questions, we aim to understand how these initiatives relate to environmental stewardship. Our results show that environmental, social, and selfmotivations are the drivers behind gardeners' participation in the gardens. It seems that involvement in the gardens provides opportunities to fulfill those needs and/or motives through different interrelated processes between the individual with him/herself, the human collective, and nature such as: contemplating nature and benefiting from sensory experiences, having access to environmental education, experiencing individual and collective organization, renewing social-ecological relationships, and facing local challenges. We note that French community gardens provide arenas for new experiences of nature. In addition, even if gardens' biophysical features and gardening practices allow a series of processes that provide social and ecological benefits and outcomes, these gardens refer to environmental stewardship practices by cultivating relational values. These values provide opportunities for innovative ways of creative conservation, reflecting how care for ourselves extends to care for others, for places, and for nature.
\end{abstract}

Key Words: community garden; conservation; environmental stewardship; experience of nature; relational values; urban; well-being

\section{INTRODUCTION}

Predominant urbanization processes are followed all over the world by so-called western consumerist values and lifestyles in urban landscapes (Meier and Lange 2009, Harvey 2013). These values and lifestyles tend to show similar social and biophysical features, such as: (1) overdependence of citizens upon cars, which limits personal interactions, generates traffic congestion, and creates public health risks and environmental damages through pollution (Davies 2015); (2) a fast-paced lifestyle, with little time for leisure and contemplation (Davies 2015); and (3) few green spaces, leading to decreasing biodiversity (Richards et al. 2017) and limited ecosystem services (Tratalos et al. 2007). Moreover, the scarcity of urban nature, combined with urban lifestyle, may hinder individual relationships with nature, leading to a phenomenon called "extinction of experience" [of nature] (Pyle 1978, 2003), which is supposed to impact human health and wellbeing, as well as emotions, attitudes, and behavior toward nature, implying in turn a cycle of disaffection toward it (Soga and Gaston 2016). Clayton et al. (2017) consider that experiences of nature are primarily defined in terms of individual contact with nature and generally recommend that the solution lies in facilitating more opportunities for such contact. The authors recognize that nature experiences are diverse and complex and are embedded in the social and political context, including (1) interactions between individuals and natural entities; (2) social and cultural context; and (3) consequences in terms of new skills, knowledge, or behavioral change (Clayton et al. 2017).

Here, we consider "nature" as a dimension of social-ecological systems; we adhere to a community of scholars who use the term social-ecological systems to qualify the complex interconnectedness among social and ecological dimensions (Berkes and Folke 1998, Folke and Gunderson 2012, Folke et al. 2016).
Community-based efforts have emerged to address socialecological dynamics in cities. Presented as "environmental stewardship" or "civic ecology" practices, these initiatives involve interactions between people, other organisms, institutions, communities, and the ecosystems in which these practices take place (Krasny and Tidball 2012). They provide opportunities to respond to social and ecological challenges (Chapin et al. 2010). Among the variety of environmental stewardship practices (e.g., community forestry, tree planting and care), community gardens have probably gained more attention because of the range of expected benefits and outcomes awarded to them (Drake and Lawson 2014). For instance, they can increase local biodiversity (Matteson et al. 2008, Matteson and Langellotto 2011); they can foster environmental learning and combat generational amnesia (Bendt et al. 2013); they can inspire and reinforce some forms of engagement toward nature and conservation (Krasny and Tidball 2012); they can increase nutritional education (Somerset et al. 2005, D'Abundo and Carden 2008); they can procure psychological benefits, mainly by reducing mental fatigue (Kaplan 1973), and promote health (Armstrong 2000); they contribute to individual, household, and community food security (Corrigan 2011); they can improve environmental sustainability (Stocker and Barnett 1998) and sustainable land uses and planning (Irvine et al. 1999); they support social processes and community development (Saldivar-Tanaka and Krasny 2004); they provide opportunities to empower residents to assist in rebuilding their environments, their lives, their sense of place and meaning following natural disasters (Chan et al. 2015). In general, they foster social-ecological system resilience following crises and disaster (Tidball and Krasny 2010a). According to these benefits and outcomes, community gardens join other urban green practices, such as collectively managed parks and allotments, notably because they promote diverse

${ }^{1}$ Centre d'Ecologie et des Sciences de la Conservation (CESCO UMR7204), Sorbonne Université, MNHN, CNRS, UPMC, BP 135, 57 rue Cuvier, 75005, Paris, France, ${ }^{2}$ Ecologie Systématique Evolution, Université Paris-Sud, UMR 8079, CNRS, AgroParisTech, Université Paris-Saclay, 91400 , Orsay, France 
learning streams, environmental stewardship, and socialecological memory (Colding and Barthel 2013). In the same line, a study conducted in allotment gardens in Stockholm revealed that these gardens provide social-ecological memories of gardening skills and local ecosystems that contribute to ecosystem services and are a source of resilience for the community (Barthel et al. 2010). Likewise, an informal management of allotment gardens fosters ecological knowledge and a sense of place that might have positive effects on local biodiversity and ecosystem services (Andersson et al. 2007).

All these processes are outcomes of environmental stewardship activities and could differ from individual motivations for engaging in such an activity. Numerous researchers have explored people's motivations for volunteering in environmental stewardship, following the framework of functional approach (Bruyere and Rappe 2007, Asah and Blahna 2013, Krasny et al. 2014). Ryan et al. (2001) identified five motivations for volunteer commitment in environmental stewardship programs: environmental help, for instance by restoring natural areas; knowledge, by learning about nature; participation in organized projects; socialization, by joining friends or meeting new people; reflection, which involves personal or emotional benefits. According to Bruyere and Rappe (2007), environmental stewardship can also be deployed by volunteers who wish to act according to their personal values; who wish to gain job-related experience or to explore new possibilities; for fun, because people already enjoy doing these kinds of activities; and just for being outdoors. Asah and Blahna (2012) added to these motivations the possibility to defend and enhance the ego. As a synthesis, Bramston et al. (2011) proposed an "Environmental stewardship motivation scale" with three categories of motivations: (1) a sense of belonging that refers to the sense of community and the social benefits; (2) caretaking the environment, encompassing themes of making an ecological contribution and a responsibility to leave something worthwhile for future generations; (3) expanding personal learning, whch refers to ecological facts and skill development. Krasny et al. (2014) completed this scale with social-ecological memories and sense of place.

A review of community gardens studies (Guitart et al. 2012) highlighted the most common motivations for participating in these initiatives: consuming fresh food, social development/ cohesion, economic issues, improving health, enhancing cultural practices, increasing knowledge, increasing land accessibility, enjoying nature, improving environmental sustainability and enhancing spiritual practice.

Considering that most of the research on community gardens has been developed in North America (Guitart et al. 2012) and that civic ecology practices reflect local conditions (Krasny and Tidball 2012), we found it pivotal to explore community gardens in the still largely unexplored French context.

\section{French community gardens}

French community gardens (FCG), commonly called "jardins partagés" (which literally translates as "shared gardens"), are increasingly popular initiatives in France. For instance, in Paris, their number increased from fewer than five in 2002 to 113 in October 2016. They emerged at the end of the 1990s (Baudelet et al. 2008), in an historical context of global enthusiasm about the environment and sustainable development. Some of them have been set up informally, occupying vacant land owned by public or private sectors, but some municipalities (e.g., Paris, Lyon, Lille, Nantes, Montpellier) have also developed programs to frame their setting (Baudelet et al. 2008). In Paris, dedicated sites are mostly vacant lands temporarily abandoned, before a new assignation or a planned construction. These sites are managed by an association, where the number of associates can range from a dozen to more than 100 persons (but in that case, associates support the initiative but do not necessarily participate in the garden activities). The designated association signs an official agreement with local authorities or landowners, which specifies the modalities of occupancy and use of the dedicated vacant land, activities, and objectives of the association (e.g., garden management, activities planned), duties of the association (e.g., organize activities for the public, respect the neighborhood, favor ecofriendly practices, avoid planting large trees or shrubs, keep the garden in "good" condition and clean) and duration of the agreement (generally 1 year, extendable up to 5 years). Municipality duties are also stated in the convention (e.g., provide equipment, adapted soil, water supply, garden enclosing) (Mairie de Paris 2012a). In addition, the association must sign the agreement "Charte Main Verte" (roughly translated as "Green Thumb Charter") and implement participatory frameworks to increase social cohesion and environmental respect (Mairie de Paris 2012b). In this political context, FCG are managed collectively by volunteers with nonprofit goals to grow flowers and/or edible plants. Although they are public, their enclosure makes their status ambiguous between public and private (Baudry et al. 2014), even though gardeners must ensure their opening at least twice a week, and the opening and closing hours as well as garden information must be displayed.

This study addresses the issue of how FCG relate to environmental stewardship. To do so, we seek to provide empirical evidence on: (1) what motivates volunteer gardeners in French community gardens to undertake this activity, (2) what practices take place in the gardens, and (3) which individual and collective processes are associated with gardeners' experiences in the gardens. We define a process as a series of actions or events that happen naturally or are taken to produce something or achieve a result (http://dictionary.cambridge.org/dictionary/english/process).

\section{METHODS}

\section{Study sites}

The Ile-de-France region hosts most of the community gardens in France, and within this region, Paris and Seine-Saint-Denis are the departments with the greatest number of gardens (Graine de Jardins 2016). Based on a preliminary mapping of all community gardens in both departments, we selected the study gardens based on their age, location, surface area, organizational structure (individual and/or collective plots), and status (perennial or ephemeral). We eventually studied seven gardens in Paris and three gardens located in the western part of the SeineSaint-Denis Department, respectively in Pré-Saint-Gervais (one garden) and in Montreuil (two gardens) (Fig. 1). The three cities represent high population density: around 21,100 inhabitants per square meter in Paris, more than 25,500 in Pré-Saint-Gervais and 11,600 in Montreuil (Institut national de la statistique et des études économiques (INSEE) 2013). 
Table 1. Features of the studied community gardens

\begin{tabular}{|c|c|c|c|c|c|c|c|c|}
\hline \multirow[b]{2}{*}{ Garden } & \multicolumn{2}{|c|}{ Location } & \multirow[b]{2}{*}{ Opening year } & \multirow[b]{2}{*}{ Surface $\mathrm{m}^{2}$} & \multirow[b]{2}{*}{$\begin{array}{l}\text { Related to a } \\
\text { green space }\end{array}$} & \multirow[b]{2}{*}{$\begin{array}{c}\text { Presence of an } \\
\text { organizer }\end{array}$} & \multirow[b]{2}{*}{ Type of plots } & \multirow[b]{2}{*}{ Status } \\
\hline & Department & City/Sector & & & & & & \\
\hline Pouce vert & $\begin{array}{l}\text { Seine Saint- } \\
\text { Denis }\end{array}$ & $\begin{array}{l}\text { Près Saint } \\
\text { Gervais }\end{array}$ & 2008 & 800 & No & No & Collective & Ephemeral \\
\hline $\begin{array}{l}\text { Ramenas Voit } \\
\text { Vert }\end{array}$ & $\begin{array}{l}\text { Seine Saint- } \\
\text { Denis }\end{array}$ & Montreuil & 2011 & 600 & Yes & No & Collective & Ephemeral \\
\hline Gobétue & $\begin{array}{l}\text { Seine Saint- } \\
\text { Denis }\end{array}$ & Montreuil & 2010 & 610 & Yes & Yes & Collective & Ephemeral \\
\hline $\begin{array}{l}\text { Jardin sur le } \\
\text { toit }\end{array}$ & Paris & 20 & 2009 & 600 & No & Yes & Collective & Ephemeral \\
\hline Leroy Sème & Paris & 20 & 2005 & 600 & No & No & Collective & Perennial \\
\hline Hérold & Paris & 19 & 2013 & 600 & Yes & Yes & $\begin{array}{l}\text { Collective and } \\
\text { individual }\end{array}$ & Perennial \\
\hline Perlimpinpin & Paris & 17 & 2008 & 170 & Yes & No & $\begin{array}{l}\text { Collective and } \\
\text { individual }\end{array}$ & Ephemeral \\
\hline Deux Lauriers & Paris & 12 & 2012 & 500 & Yes & No & Collective & Ephemeral \\
\hline $\begin{array}{l}\text { Victor } \\
\text { Schultzer }\end{array}$ & Paris & 10 & 2009 & 560 & No & No & Collective & Perennial \\
\hline Périchaux & Paris & 15 & 2009 & 350 & No & No & $\begin{array}{l}\text { Collective and } \\
\text { individual }\end{array}$ & Ephemeral \\
\hline
\end{tabular}

Fig. 1. (a) Map of France showing the location of the departments Paris and Seine-Saint-Denis. (b) Study community gardens in both departments. Paris (in gray) is divided in 20 sectors ("arrondissements"); the Seine-Saint-Denis department (in white) is divided in cities.

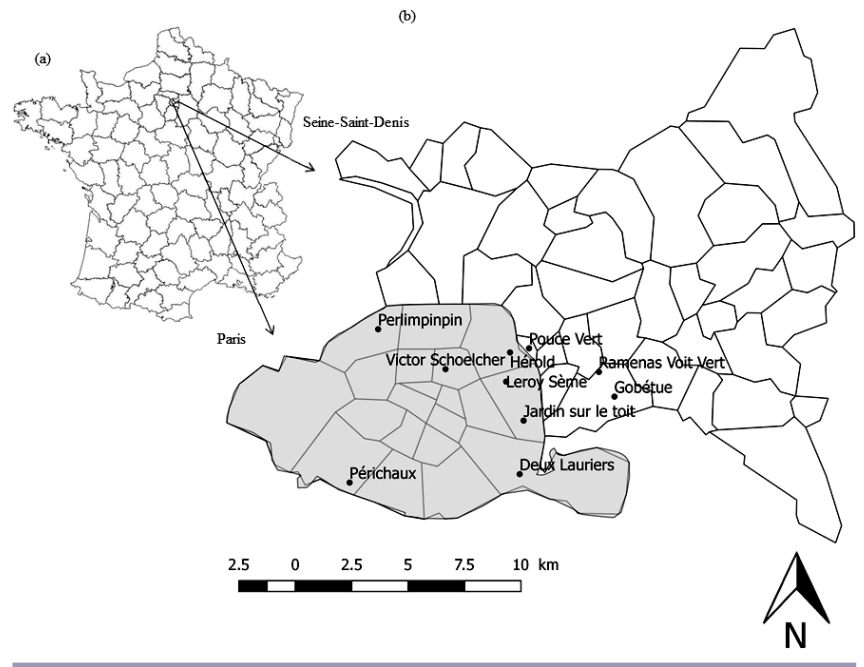

The 10 studied community gardens differ in their features (Table 1), notably in their surface areas (mean: $570 \mathrm{~m}^{2}$, range: $170-800$ $\mathrm{m}^{2}$ ) and age (4-10 years old). Four gardens are located near other green spaces: Ramenas Voit Vert is located next to a children's playground with vegetation, Gobétue is located within a historical peach orchard, Perlimpinpin is in a public garden, and Deux Lauriers is in an old abandoned railway. Three gardens include organizers (one person employed in Le jardin sur le toit, two in Herold and Gobétue). In three gardens, individual plots are cultivated in addition to collective plots. Finally, most gardens (seven out of 10) have an ephemeral status. After the fieldwork was conducted (in 2014-2015), the garden Pouce Vert was closed by the municipality of Pré-Saint-Gervais. In the 10 studied gardens, we carried out ethnographic qualitative work, including participant observations and semistructured interviews (Beaud and Weber 2010). All field studies were conducted by a single researcher, ACT.

\section{Participant observations}

From June to December 2014, participant observations were conducted in the gardens to understand ongoing individual and social processes and gardening practices. Each study garden was visited at least 10 times throughout the study, and each visit lasted at least 2 hours. Some visits occurred during social events, such as concerts, picnics, or workshops taking place in the gardens. All observations were recorded by means of field notes and pictures. Pictures were used as mnemonic material, and field notes were analyzed through an inductive method, in order to build an interview guide for further semistructured interviews.

\section{Semistructured interviews}

By using semistructured interviews, we provided a flexible and reflective framework, allowing the gardeners to express their conscious and tacit motivations and their experiences in the gardens. This framework provided a comfortable atmosphere to talk and gave gardeners enough time to put their experiences into words throughout the conversation.

From January to September 2015, ACT conducted semistructured interviews with 30 community gardeners and randomly asked a list of predefined questions (Table 2). The interviews were individual and took place in the gardens. They were recorded, transcribed, and anonymized; notes were also taken during the interviews. Saturation (Strauss 1987) was reached after 30 interviews, when we could gain no additional information. All interviewed gardeners were regular users of the garden, i.e., they were present and practicing in the garden at least once a week. Interviews were aimed at understanding the first motivations of gardeners for participating in the garden and to 
confirm, through gardeners' narratives, the gardening practices and processes recorded during the participant observations. The interviews were run on a voluntary basis and lasted on average $1 \frac{1}{2}$ hours (range: $40 \mathrm{~min}-3 \mathrm{~h} 30 \mathrm{~min}$ ). From one to five gardeners were interviewed per garden, depending on the willingness of participants.

Table 2. Questions used during the interviews and their relationship to the three study questions

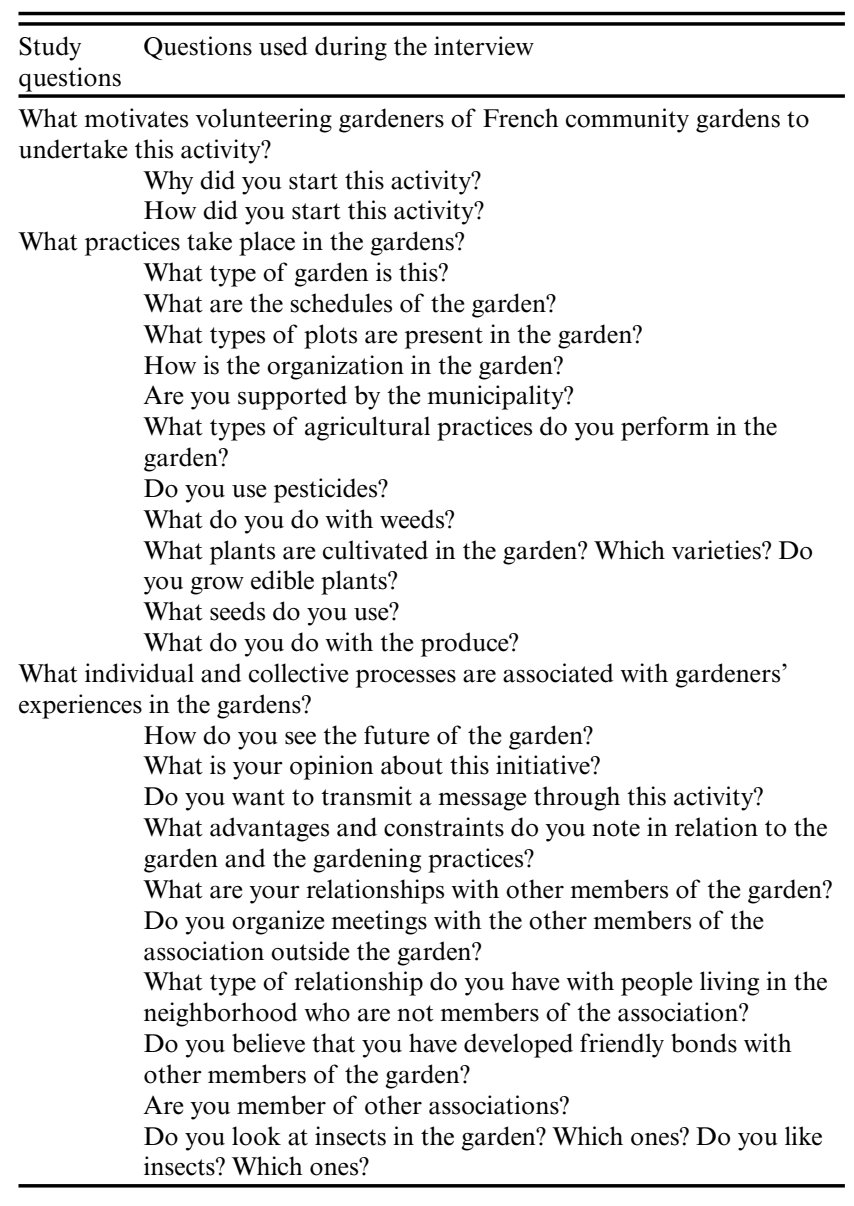

\section{Interviewed community gardeners}

Individual characteristics of the 30 people interviewed are summarized in Table 3.

\section{Qualitative data analysis}

Following the principles of structural and elaborative coding (Saldaña 2009), we coded the notes taken during participant observations. Through several cycles of coding, we filtered, focused, and highlighted the salient features in our data. We then used this coding to analyze the interviews with the gardeners and classified gardeners' motivations for starting to volunteer, their gardening practices, and individual and collective processes associated with this practice. This combined method linking participant observation and openended interviews has been already used in similar studies (e.g., Barthel et al. 2010, Krasny et al. 2012, Bendt et al. 2013). Combining information on what people do and say, recognize gardeners' motivations and processes emerging in gardens.
Table 3. Interviewed community gardeners

\begin{tabular}{|c|c|c|c|}
\hline \multicolumn{4}{|c|}{$\begin{array}{l}\text { Respondent } \\
\text { number }\end{array}$} \\
\hline & Sex & Age & Current occupation \\
\hline 1 & Male & $40-60$ & $\begin{array}{l}\text { Unskilled work and precarious jobs (i.e., } \\
\text { part-time employment or temporary work)) }\end{array}$ \\
\hline 2 & Female & $40-60$ & $\begin{array}{l}\text { Association with environmental and social } \\
\text { objectives (i.e., environmental education, } \\
\text { sustainable development, social or } \\
\text { environmental organizer) }\end{array}$ \\
\hline 3 & Male & $40-60$ & Unskilled work and precarious jobs \\
\hline 4 & Female & $20-40$ & Student \\
\hline 5 & Female & over 60 & Unemployed \\
\hline 6 & Female & over 60 & Unemployed \\
\hline 7 & Male & $40-60$ & Unemployed \\
\hline 8 & Male & over 60 & Retired \\
\hline 9 & Male & over 60 & Retired \\
\hline 10 & Female & $40-60$ & $\begin{array}{l}\text { Association with social purposes (back-to- } \\
\text { work organizations) }\end{array}$ \\
\hline 11 & Female & $40-60$ & $\begin{array}{l}\text { Creative works (i.e., working in art or } \\
\text { design) }\end{array}$ \\
\hline 12 & Male & $40-60$ & $\begin{array}{l}\text { Job related to trade (i.e., business, } \\
\text { administration and commerce) }\end{array}$ \\
\hline 13 & Male & $40-60$ & Creative work \\
\hline 14 & Female & $40-60$ & Job related to trade \\
\hline 15 & Male & $40-60$ & $\begin{array}{l}\text { Association with environmental and social } \\
\text { objectives }\end{array}$ \\
\hline 16 & Female & $40-60$ & Unemployed \\
\hline 17 & Male & $40-60$ & Unemployed \\
\hline 18 & Female & $20-40$ & Unemployed \\
\hline 19 & Female & $40-60$ & Association with social purposes \\
\hline 20 & Female & $40-60$ & Unemployed \\
\hline 21 & Male & $20-40$ & Job related to trade \\
\hline 22 & Male & $40-60$ & $\begin{array}{l}\text { Association with environmental and social } \\
\text { objectives }\end{array}$ \\
\hline 23 & Male & $20-40$ & $\begin{array}{l}\text { Association with environmental and social } \\
\text { objectives }\end{array}$ \\
\hline 24 & Male & over 60 & $\begin{array}{l}\text { Technical job (i.e., computer systems or } \\
\text { engineer) }\end{array}$ \\
\hline 25 & Female & over 60 & Retired \\
\hline 26 & Male & over 60 & Retired \\
\hline 27 & Male & over 60 & Retired \\
\hline 28 & Female & $20-40$ & Job related to trade \\
\hline 29 & Male & $20-40$ & Technical work \\
\hline 30 & Male & $20-40$ & $\begin{array}{l}\text { Association with environmental and social } \\
\text { objectives }\end{array}$ \\
\hline
\end{tabular}

The coding was carried out by author ACT, who conducted the interviews and participant observations. However, results were thoroughly discussed throughout the process by all three authors to reach consensus and ensure reliable assessment validity.

Features that emerged during the analyses were put in dialog with the theoretical propositions coming from environmental stewardship framework and conservation sciences.

\section{RESULTS}

\section{Gardeners' motivations for participating in French community gardens}

\section{Environmental motivations}

Fourteen out of the 30 interviewed gardeners declared that their first motivation for getting involved in the garden was environmental. We grouped in this category all the declared motivations that encompassed the will to make an ecological 
contribution to the environment and the feeling of responsibility toward the environment. We also included here all the expressions of willingness to increase individual or collective experiences of nature or being outdoors, including learning and educating about nature and human-nature interactions, as follows:

The desire to contribute to biodiversity conservation by improving urban biodiversity and raising people's awareness about human-nature relationships:

I want to raise public awareness about the importance of bees, butterflies, and other pollinating insects who, by their endless activity to survive, also allow human beings to eat, tomatoes and the like. I want to contribute to biodiversity by growing plants that are visited by a certain biodiversity, and in this way, bring bees and other pollinating insects into cities (Respondent 15).

The desire to increase individual contact and experience of nature:

Although I've always lived in a city, I've always had a need for nature, and I take every opportunity to get away from Paris. Since I can't get away all the time, I need to bring nature into Paris. I started with having plants at home, having plants on the balcony, and lately, I discovered the community gardens (Respondent 19).

The desire to have an outdoor activity, without specific emphasis on nature:

In my country I was always outdoors, I come from rural area...I joined the community garden because it is a pleasure for me, a hobby, what we want is to relax... (Respondent 8).

The desire to transmit a nature experience to their children:

I used to live in a house with a garden, so I've had the chance to interact with nature, see animals, plants growing... I want my kids to have the same experience, I don't want them to believe that fish are square, that cows are purple, or that tomatoes grow in supermarkets (Respondent 28).

\section{Self-motivations}

Ten out of the 30 interviewed gardeners declared that their first motivation for participating in the garden was to deal with a disturbance, stress, or shock in their personal life, as follows:

Break in employment: gardening started after having stopped working because of retirement or dismissal:

When I retired, I didn't have anything to do, I had so much time, it was difficult... With the garden, I started meeting people; Ispendmy time growing plants, enjoying nature... (Respondent 25).

I had an intellectual job... computing... somehow I lost control of my life. I lost my work and it made me... let's say lose my benchmarks. I questioned many things. And the act of returning to nature allows me to rethink my values (Respondent 7).

Break in routine; one gardener referred to an accident that broke his routine:
I had an accident at my work and I broke my shoulder, I'm on sick leave for several months... I live nearby, so I come to see the plants... for me it is a pleasure... I love nature, when I don't feel well, I spend some time here and everything goes better (Respondent 1).

Another gardener started this activity to break from his everyday routine:

I have a daily routine of commuting from work to home... when I come here, I can talk to people from different backgrounds: elderly or young people, couples... a huge variety of people to whom I would never speak otherwise... Here in the garden, we can forget the passing of time... here it's quiet, there are birds, smells of nature... (Respondent 3).

Personal and psychological restoration; gardening was perceived as providing happy breaks in nature, in a specific moment of their lives, when people were going through existential questioning or crisis:

It was a personal process. Without going into too much detail... the so-called 40-year-old crisis; it was a kind of personal questioning, a growing awareness about the aim of life... about existential questions... So, I was drawn to go back to basic things of life, like nature but also social relationships based on sharing... things like that (Respondent 13).

Other gardeners declared that they entered the garden through the reliving of positive past experiences:

When I was a kid, I used to do gardening quite often with my grandmother and I loved that. I've had difficult times in my life and I started to come in this garden because gardening makes me feel good; I remember happy and peaceful moments (Respondent 30).

Social motivations

Finally, six out of 30 interviewed gardeners said that they began participating in the garden for social reasons, as follows:

A desire to build social bonds:

I wanted to meet people with whom I could share the pleasure and interest in growing. And actually it was the only way to know people from my neighborhood (Respondent 6).

A desire to create new social interactions in the city in general:

I wanted to question the way we live in the city, particularly in public spaces, and how we can appropriate the city through nature, use it to express ourselves, meet people, and thus challenge society on how to think about society and our relationship to nature (Respondent 23).

\section{Gardening practices}

Gardeners do not use any chemicals, they use ecological and organic processes or treatments to avoid pests: they mix crops, they use natural enemies (e.g., ladybirds), they prepare natural insecticides (e.g., slurry of nettles), or they trap slugs in beer traps. These were learned from external sources (books, internet, gardening courses), but also by imitating other gardeners' 
practices, or by an explicit transmission of knowledge from a gardener or an organizer to another gardener. Also, Le Pouce Vert has developed a program for composting and recycling Christmas trees that involves inhabitants from the neighborhood. In gardens with collective plots, the decisions concerning land uses and practices are taken collectively. Negotiations are needed to quell emerging conflicts. These conflicts are less common in gardens with organizers, because the organizer chooses and allocates land uses him/herself.

In every single garden, flowering plants are grown to attract insect pollinators. In all gardens but Victor Schoelcher, the gardeners install human-built structures to attract and host insects (insect hotels) and birds (nest boxes). In all gardens but Perichaux, gardeners preferentially grow traditional varieties of plants instead of varieties from the official French national catalog. They buy seeds from specific associations such as Kokopelli (Kokopelli 2016), exchange seeds with other community gardens or associations, such as Incredible Edibles (Incroyables comestibles Paris 2016). Nevertheless, due to difficulties in buying seeds from associations (e.g., purchasing by internet, do not always have stock for all varieties), the gardeners also buy seeds in garden centers like Truffaut (Truffaut 2016). They also harvest their own seeds in the garden. In Herold garden, gardeners grow crops originating from the home country of one of the gardeners. Two gardens (Leroy Sème and Le Pouce Vert) have ponds, and five gardens include specific unmanaged areas devoted to spontaneously growing vegetation (i.e., wild plants). In French culture, wild plants growing spontaneously in gardens are often perceived negatively and are termed weeds (Menozzi 2007). Yet, most interviewed gardeners referred to wild plants not as "bad" but as opportunistic plants, and they also used the term "adventitious" to qualify them. In individual plots, the control of these plants is based on individual willingness: some gardeners dig them out and compost them; others leave leguminous plants to nourish the soil, to observe their flowers, or to discover potential new uses (for food, drink, fertilizer, etc.). In collective plots, weeds are more or less controlled and removed depending on the garden (removed weeds are always composted): in Herold, based on the organizers' advice, leguminous plants are kept as a cover crop that helps fix nitrogen in the soil; some weeds are left because they can be used as food (e.g., Taraxacum officinalis) or medication (e.g., Borago officinalis). In Perichaux collective plots, weeds are removed only in the trails. In Jardin sur le toit and Gobétue, they are mechanically removed only in areas where crops are grown. The same treatment is applied in Le Pouce Vert and Deux Lauriers, where gardeners make sure they keep wild plant species because they believe they offer habitat for animals. Finally, in Leroy Sème, Ramenas voit vert, and Perlimpinpin, weeds are systematically removed.

Furthermore, activities such as picnics, workshops, concerts, or balls are developed in all gardens except for Victor Schoelcher garden. These activities are led by the organizers if the garden has one. Elsewhere, they are organized by the gardeners themselves or anyone willing to become involved in the organization of such events.

\section{Processes taking place in the gardens}

Individual motivations for participating in the gardens and ongoing activities in the garden allow diverse types of individual and social processes to emerge, as follows:
Nature contemplation and sensory experiences

The first thing I did was to observe... Before, I thought plants could grow spontaneously... Then I started to compost fruits and vegetables peelings, to plough, and I love it. I put my hands into the soil, it's relaxing, it makes me feel good. Pay attention, check whether I have to trim or remove something, look at earthworms, I love it (Respondent 5).

We have so many ideas about nature, but it is different to concretely implement them in the field, to observe the impact on the soil or on plants. Here, luckily, we can make experiments in the garden without pressure, it makes you forget your problems, it makes you feel good... when I'm here, I don't feel time passing (Respondent 14).

\section{Environmental education}

Why does the acanthus grow close to the artichoke? Because they grew up there, by chance. The acanthus settled almost without any help, and then we learned that both plants interact with each other, that ladybirds deposit larvae in the acanthus, and then move to the artichoke to eat aphids(Respondent 9).

... Here luckily, we have $X$, who is fascinated by insects and who is fascinating when speaking about them, very pedagogical. He transmits to us all his respect and admiration toward insects. I read a lot about animals, but it's not the same when listening to someone, meeting someone showing them to us, teaching us about them (Respondent 6).

I remember, there was a Moroccan guy who used to pass by very often and who eventually entered in the garden once with his son. This man knew a lot about gardening, and he started teaching us. His son was very proud of his father teaching us. I didn't know much, and this man was teaching us how to grow beans (Respondent 10)

\section{Individual and collective organization}

Some gardeners planned personal and collective small business activities in relation to gardening, outside the garden, and some gardeners developed personal and collective projects in the garden, such as:

We will become a counselling society; in fact, in some places we already give advice to other gardens. On Thursday, we went to another garden to give them help with our tools (Respondent 8).

We organize workshops to permit children to interact with nature. They come to discover... Once there were lots of spiders in the garden, some children were frightened, but gradually we helped them to overcome their fear and we allowed them to discover the role of animals in the garden... (Respondent 19).

Renew social-ecological relationships Gardening has a broader meaning for me, it is not only growing plants, it's everything that involves relationships 
among human beings, and relationships with animals, the relationships with the biotope (Respondent 30 ).

In the garden, there exists a social diversity, however, despite the differences, with time, we have developed common values, we became conscious of the environment (Respondent 22).

Facing local challenges

Participatory gardening helped solve some local issues, such as soil pollution:

\begin{abstract}
There was suspicion of pollution with heavy metals in the soil... So, they told us, precautionary principle: you must not eat what you grow here, notably because there will be children, pupils, etc. visiting the garden. So, even if it is really frustrating, we found the solution... off-ground cultivation in bins or on straw, with healthy soil (Respondent 14).

We don't know if the land is good... But with time we can recognize a soil with a good quality, or sandy, or polluted... So we became skilled at assessing the soil. And on the contrary, we say: maybe here we should grow things... maybe the soil will recover with time, maybe we will demonstrate that this land was not that bad; and that we can also make a garden even if we can't eat what we grow (Respondent 30).
\end{abstract}

Facing the risk of garden's closure

The garden will disappear; they will build something here instead... we have fought to keep the garden, we have demonstrated that gardens play a role in offering children animations and activities such as drawing, painting, gardening, or nature observation... There is also the Agenda 21 almost nowhere applied... but nevertheless in the critical climatic context, it is very important to do something, as we have done. Within 6 years, we have created a biotope, it is really important, we have a lot of diversity. We also play a role in the reduction of waste in the city; we have made people change their habits, and they compost organic wastes... (Respondent 5).

\section{DISCUSSION}

\section{Gardeners' first motivations for participating in French community gardens}

Through qualitative research, we explored the first motivations of regular users of FCG for volunteering in these activities. Our study supports previous studies of environmental stewardship volunteer motivations, designed by the authors as following: helping the environment (Ryan et al. 2001), environmental purposes (Asah and Blahna 2012) or caring for the environment (Bramston et al. 2011); learning (Ryan et al. 2001); social motivations (Ryan et al. 2001), social interactions (Asah and Blahna 2012), or social belonging (Bramston et al. 2011), reflection (Bruyere and Rappe 2007) or defending and enhancing the ego (Ryan et al. 2001, Asah and Blahna 2012). However, despite their apparent diversity, these motivations for starting to garden are all interrelated and enter in our classification in environmental, self, and social motivations. Based on our results, we propose enlarging these three categories of motivations, as follows:

Environmentalmotivations: this category includes the motivations "helping or caring for the environment" or "environmental purposes motivations," which refer mostly to restoration of natural areas. However, our results showed that gardeners refer to a much wider diversity of actions to enhance the environment, including: raise people's awareness about human-nature relationships, learn and educate about nature and human-nature interactions, and promote adults' and children's experiences of nature or "outdoors." Thus, we propose including in this category the learning motivations (e.g., Ryan et al. 2001) and the "being outdoors" motivation proposed by Bruyere and Rappe (2007). This is particularly important, as the reduction of nature experiences is caused not only by a lack of nature in urban areas, but also by lifestyle factors (Pergams and Zaradic 2006). Thus, greater experiences of nature could be gained by promoting interactions of people (including children) with nature across a range of urban habitats (Crumley 2000, Barthel et al. 2010, Hand et al. 2017). We also included the wish to make direct contact with nature, which is part of the experiences referred to above; it has been proposed as an important predictor of ecological behaviors (Mayer and Frantz 2004; Soga and Gaston 2016).

Self-motivations: this category includes the "reflection" motivation (Ryan et al. 2001), which involves personal or emotional benefits from volunteering, as well as the "escape" motivation (Asah and Blahna 2012) that refers to getting away from the stressful demands of everyday life. In our case, all motivations belonging to this category were driven by stress or shock in gardeners' personal lives. Indeed, all gardeners who mentioned this motivation referred to increased well-being after having started this activity. This result is consistent with the literature, which shows a positive relationship between regular contacts with nature and health: psychological well-being or mental distress (Keniger et al. 2013, White et al. 2013; Hartig et al. 2014, Shanahan et al. 2015, McCracken et al. 2016), general health (Kardan et al. 2015) or general mood (Capaldi et al. 2014). However, in addition to these direct benefits, we propose including in this category symbolic meanings, mostly based on recollections and memories. Indeed, some gardeners evoked remembrances about gardening experiences or places they visited during childhood, together with associated well-being This could support the proposition of Krasny et al. (2014) about the sense of place as an important driver of environmental volunteering. Nevertheless, here, remembrances used as the first motivation to become involved in the garden are associated with autobiographical memory more than social-ecological memories as proposed by Krasny et al. (2014).

Social motivation: this category includes the social motivations proposed by Bruyere and Rappe (2007) and by Asah and Blahna (2012), especially in terms of meeting people and building social bonds. However, we propose also including in this category the gardeners' wish to build new social interactions that will challenge social and ecological issues, also referred to as "community motivations" (Asah and Blahna 2012).

Our results are, therefore, largely consistent with previous studies on motivations for volunteering in community gardens in other contexts, showing the importance given by people to these aspects, 
whatever the context. Interestingly, our interviewed gardeners mentioned only some of the motivations already expressed in the literature, and not the whole range previously recorded.

Compared with motivations expressed in other community garden studies (Guitart et al. 2012), motivations recorded in FCG included neither fresh food consumption nor economic issues. This might be because FCG did not appear in a context of food deprivation or economic depression, contrary to other community gardens elsewhere in the world (e.g., Victory gardens in New York). In addition, although some gardeners are unemployed, the French system of unemployment insurance can buffer their economic difficulties. Food issues are sometimes mentioned in the interviews, but as an educational purpose, not as means of survival. Finally, increasing land accessibility, enhancing spiritual practice, project organization, values and esteem, career, or getting exercise, were not mentioned as primary motivations for participating in the gardens. As people's motivations may change over time (Ryan et al. 2001), further research is needed.

\section{Gardening practices}

Due to gardening practices, most FCG present biophysical features that favor biodiversity. Indeed, the diversity of land uses together with the presence of uncultivated areas (small wastelands) and ponds provide diverse habitats for wild species. Flowering plants, insect hotels, and nest boxes provide resources (food and refuge) for wild fauna (Cannon 1999, Gaston et al. 2005a, b); compost systems nourish the soil through nutrient supply and carbon sequestration (Martínez-Blanco et al. 2013) and provide habitat for many species (see Ødegaard and Tømmerås 2000). Also, some gardens are located in urban green areas and can potentially act as ecological corridors, therefore improving connectivity between buffer zones (Palomino and Carrascal 2006, Goddard et al. 2010 , Serret et al. 2014). Thus, FCG could be important places to consider for purposes of urban biodiversity conservation. More generally, the environmentally friendly gardening practices implemented in the gardens differ from French normative representations of what a garden should be, i.e., very much controlled and totally devoid of wild plants (e.g., Thomas 1983). Two specific normative and prescriptive visions are challenged in the study gardens. First, in the majority of the study gardens, gardeners let weeds grow, often out of curiosity, to discover their potential impact on other species and their potential human uses. This is in contrast to the systematic weed control generally implemented by farmers and gardeners to increase crop productivity (Fuhlendorf et al. 2009) and may be due to the fact that the main objective of these gardens is not food production. Second, gardeners use traditional seed varieties in contrast to the official recommendation to use those from official catalogs. The official seeds are sterile (they are mostly F1 hybrids) and prevent any local adaptation of the crops to human practices and local environmental conditions (Demeulenaere 2014). However, the choice not to use official seeds is presented by the gardeners as a protest against the normative agricultural system and a willingness to participate in an alternative to the seed industry. This is, however, difficult to translate into practice because of the current French regulations and difficulties in accessing traditional seeds. Social networks allowing seed purchase and exchanges are nevertheless very well organized and foster social capital (Bodin and Crona 2008). Social events organized in most of our study gardens are also occasions for gardeners to build in a community (Saldivar and Krasny 2004) and increase social capital.
Finally, as Barthel et al. (2010) proposed for allotments, FCG are places where social-ecological memories are important, through education and transmission, but also through conflict solving and negotiation toward collective management.

\section{Processes taking place in the gardens}

Our study highlighted how community gardens provide opportunities for individual and collective dynamic processes toward nature.

First, gardeners attach great importance to their sensory interactions with nature through vision, hearing, sense of smell, or touch. This is highly consistent with the literature showing that experiences of nature engage multiple senses, notably smells and tactile sensations that are greater in natural than in human-built contexts (Kaplan and Kaplan 1989). Through these sensory experiences, gardeners consider their activities in the garden (e.g., growing plants, composting, observing plants and animals) as something contemplative and fascinating that makes them forget their worries, feel the time slow down, and feel good and relaxed. These results corroborate research showing the restorative effects of natural experiences, mainly through reducing mental fatigue (Kaplan and Kaplan 1989, Hartig et al. 1991, Kaplan 1995), emotional and physiological stress recovery, stress reduction (Ulrich 1979, Hartig et al. 2003, 2011), and the feeling of being away from everyday routine (Hartig et al. 1991, Kaplan 1995). Other authors highlighted the benefits of exposure to natural environments on individual health and well-being (Maller et al. 2005, Maas 2006, Bowler et al. 2010, Hartig et al. 2014), particularly gardening (Soga et al. 2017).

These sensory experiences are not only self-dedicated, they can also be used in educational processes in the gardens (as noted by Schama 1995, Misztal 2003, Murdoch 2006). More generally, environmental education in the gardens is about far more than environmental conservation (like in main environmental education frameworks, Bengtsson 2016), but refers to human relationships with and within the environment (see Berryman and Sauvé 2016). Because it is place based, this education can integrate learning about local social-ecological dynamics (Tidball and Krasny $2010 b$ ), even in cities. As such and besides their specificities, FCG, as other community gardens, are key arenas for environmental education (Ferris et al. 2001, Krasny and Doyle 2002, Doyle and Krasny 2003, Bendt et al. 2013).

Indeed, some gardeners have constructed alone or collectively projects and/or their own business, such as consulting societies that allow unemployed, retired, and job-dissatisfied gardeners to cope with diverse types of individual wishes or needs. Hence, gardens constitute ideal arenas to turn acquired knowledge into a range of activities, such as garden management, communication, public advertisement, or negotiation. These collective dynamics can be strongly encouraged by the presence of key individuals, such as organizers or some gardeners, acting as social and environmental catalysts who provide leadership, trust, vision, and meaning (see Folke et al. 2005). These people play a crucial role in activating the social capital (Krishna 2002), in addition to collective organization.

As mentioned above, it is now widely acknowledged that urban green spaces may play an important role in preserving biodiversity, notably by providing natural habitats (Gaston et al. 2005b, Kadlec et al. 2008, Loram et al. 2008, Kowarik 2011, van Heezik et al. 
Fig. 2. Schematic representations of social-ecological dynamics in French community gardens

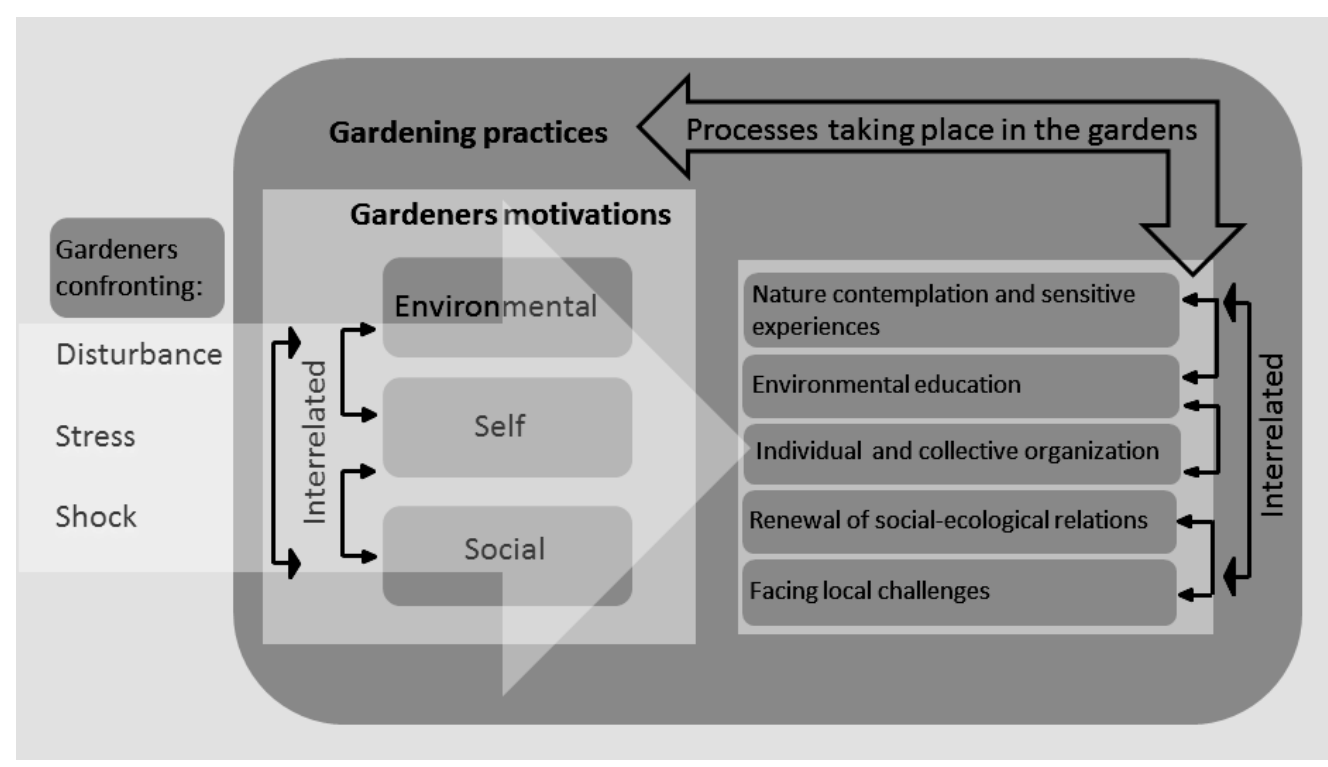

2012). Our study goes one step further, and thus supports previous studies by showing that FCG are also very important for maintaining relationships in cities, not only toward nature but also among people (Barthel et al. 2010, Bendt et al. 2013). Gardeners can develop new social relationships with people in the garden, with people living close to the garden, as well as with people from other community gardens or associations, in solidarity networks. As Agustina and Beilin (2012:447) mentioned, "community gardens provide a space to make the unfamiliar familiar." In our case, through gardening, gardeners renew their relationship to the urban way of life, to natural entities, or to society. This is consistent with the literature, showing that community gardens contribute to improving neighborhood involvement (Armstrong 2000), social cohesion (Shinew et al. 2004, Maas et al. 2009, Francis et al. 2012, de Vries et al. 2013), and social inclusion (based on shared norms and values, positive and friendly relationships, and feelings of belonging) (Hartig et al. 2014).

These renewed relationships can help gardeners face local challenges. The two most common challenges are (1) competition for land use in a densification context (Schmelzkopf 1995) and (2) soil pollution (Armstrong 2000, Wakefield et al. 2007). Gardeners develop a sense of place (Stedman 2002) that makes painful the possibility of a garden's closure. Interestingly, even if local challenges are considered as negative experiences, they did not prevent any action. Instead, they were considered as opportunities for people to learn about these problems and to face them creatively. Likewise, gardeners are confronted with systemic difficulties or world visions (e.g., concerning seed provisioning, weed control, legal constraints for crops). However, the different dynamic processes going on within the garden allow some gardeners to develop the ability to adaptively deal with these issues. Nevertheless, following Colding and Barthel (2013), these external and administrative constraints could restrict the capacity of citizens to practically engage in urban social-ecological systems.

\section{CONCLUSION}

In this study, we showed a diversity of social-ecological dynamics associated with community gardens. All these processes are closely interrelated (Fig. 2) with feedback loops and take place in different dimensions (individuals, groups and nature).

We observe that people volunteer for the same activity for diverse needs and/or motives. The involvement in the gardens affords opportunities to fulfill those needs and/or motives through different interrelated processes between the individual with him/ herself, the human collective, and nature. Thus, FCG provide arenas for transforming experiences of nature (Clayton et al. 2017). By allowing transformed experiences of nature, community gardens enhance both urban nature and people's wellbeing. But FCG can be considered as environmental stewardship practices for other reasons, notably because they provide creative ways to respond to urban challenges. In addition, we could say that apart from cultivating plants, these gardens allow cultivation of new values, i.e., relational values, defined as values not given to things but derivative of relationships and responsibilities to them (Chan et al. 2016). Indeed, the garden is not important in itself but becomes important because it allows the different dimensions of a social-ecological system to be connected. The values that are encouraged in these places provide opportunities for innovative creative conservation (see Chan et al. 2016), which reflects how caring for ourselves extends to caring for others, place, and nature.

Without claiming that community gardens can cope alone with urban challenges and conservation, we highlighted their relevance at the local level, as places that permit citizens to reconsider social and ecological interdependencies. Further studies are needed to evaluate their social-ecological impacts at a larger scale in space and time.

Responses to this article can be read online at: http://www.ecologyandsociety.org/issues/responses. $\mathrm{php} / 9442$ 


\section{Acknowledgments:}

The authors wish to thank all interviewees who participated in this study. We thank Carole Vuillot, the two anonymous reviewers, and the editor for their relevant comments. Finally, we acknowledge with thanks the research funding provided by the Ecuadorian National Secretary of Higher Education, Science and Technology (SENESCYT).

\section{LITERATURE CITED}

Agustina, I., and R. Beilin. 2012. Community gardens: space for interactions and adaptations. Procedia-Social and Behavioral Sciences 36:439-448. http://dx.doi.org/10.1016/j.sbspro.2012.03.048

Andersson, E., S. Barthel, and K. Ahrné. 2007. Measuring socialecological dynamics behind the generation of ecosystem services. Ecological Applications 17(5):1267-1278. http://dx.doi. org/10.1890/06-1116.1

Armstrong, D. 2000. A survey of community gardens in upstate New York: implications for health promotion and community development. Health and Place 6:319-327. http://dx.doi. org/10.1016/S1353-8292(00)00013-7

Asah, S. T., and D. J. Blahna. 2012. Motivational functionalism and urban conservation stewardship: implications for volunteer involvement. Conservation Letters 5(6):470-477. http://dx.doi. org/10.1111/j.1755-263X.2012.00263.X

Asah, S. T., and D. J. Blahna. 2013. Practical implications of understanding the influence of motivations on commitment to voluntary urban conservation stewardship. Conservation Biology 27(4):866-875. http://dx.doi.org/10.1111/cobi.12058

Barthel, S., C. Folke, and J. Colding. 2010. Social-ecological memory in urban gardens-retaining the capacity for management of ecosystem services. Global Environmental Change 20(2010):225-265. http://dx.doi.org/10.1016/j.gloenvcha.2010.01.001

Baudelet, L., F. Basset, and A. Le Roy. 2008. Jardins partagés: utopie, écologie, conseils pratiques. Terre vivante, Meris, France.

Baudry, S., J. Scapino, and E. Rémy. 2014. L'espace public à l'épreuve des jardins collectifs à New York et Paris. Géocarrefour 89(1-2):41-51. http://dx.doi.org/10.4000/geocarrefour.9388

Beaud, S., and F. Weber. 2010. Guide de l'enquête de terrain. Fourth edition. La Découverte, Paris.

Bendt, P., S. Barthel, and J. Colding. 2013. Civic greening and environmental learning in public-access community gardens in Berlin. Landscape and Urban Planning 109:18-30. http://dx.doi. org/10.1016/j.landurbplan.2012.10.003

Bengtsson, S. L. 2016. Hegemony and the politics of policy making for education for sustainable development: a case study of Vietnam. The Journal of Environmental Education 47(2):7790. http://dx.doi.org/10.1080/00958964.2015.1021291

Berkes, F., and C. Folke. 1998. Linking social and ecological systems: management practices and social mechanisms for building resilience. Cambridge University Press. Cambridge, UK.

Berryman, T., and L. Sauvé. 2016. Ruling relationships in sustainable development and education for sustainable development. The Journal of Environmental Education 47(2):104117. http://dx.doi.org/10.1080/00958964.2015.1092934

Bodin, Ö., and B. I. Crona. 2008. Management of natural resources at the community level: exploring the role of social capital and leadership in a rural fishing community. World Development 36(12):2763-2779. http://dx.doi.org/10.1016/j. worlddev.2007.12.002

Bowler, D. E., L. M. Buyung-Ali, T. M. Knight, and A. S. Pulin. 2010. A systematic review of evidence for the added benefits to health of exposure to natural environments. BMC Public Health 10:456. http://dx.doi.org/10.1186/1471-2458-10-456

Bramston, P., G. Pretty, and C. Zammit. 2011. Assessing environmental stewardship motivation. Environment and Behavior 43(6):776-788. http://dx.doi.org/10.1177/0013916510382875

Bruyere, B., and S. Rappe. 2007. Identifying the motivations of environmental volunteers. Journal of Environmental Planning and Management 50(4):503-516. http://dx.doi.org/10.1080/09640560701402034

Cannon, A. 1999. The significance of private gardens for bird conservation. Bird Conservation International 9(4):287-297. http://dx.doi.org/10.1017/S095927090000349X

Capaldi, C. A., R. L. Dopko, and J. M. Zelenski. 2014. The relationship between nature connectedness and happiness: a meta-analysis. Frontiers in Psychology 5(976):1-15. http://dx.doi. org/10.3389/fpsyg.2014.00976

Chan, J., B. DuBois, and K. G. Tidball. 2015. Refuges of local resilience: community gardens in post-Sandy New York City. Urban Forestry and Urban Greening 14:625-635. http://dx.doi. org/10.1016/j.ufug.2015.06.005

Chan, K. M. A., P. Balvanera, K. Benessaiah, M. Chapman, S. Díaz, E. Gómez-Baggethun, R. Gould, N. Hannahs, K. Jax, S. Klain, G. W. Luck, B. Martín-López, B. Muraca, B. Norton, K. Ott, U. Pascual, T. Satterfield, M. Tadaki, J. Taggart, and N. Turner. 2016. Opinion: why protect nature? Rethinking values and the environment. Proceedings of the National Academy of Sciences 113(6):1462-1465. http://dx.doi.org/10.1073/pnas.1525002113

Chapin, F. S., S. R. Carpenter, G. P. Kofinas, C. Folke, N. Abel, W. C. Clark, P. Olsson, D. M. Stafford Smith, B. Walker, O. R. Young, F. Berkes, R. Biggs, J. M. Grove, R. L. Naylor, E. Pinkerton, W. Steffen, and F. J. Swanson. 2010. Ecosystem stewardship: sustainability strategies for a rapidly changing planet. Trends in Ecology and Evolution 25(4):241-249. http://dx. doi.org/10.1016/j.tree.2009.10.008

Clayton, S., A. Colléony, P. Conversy, E. Maclouf, L. Martin, A. C. Torres, M. X. Truong, A. C. Prévot. 2017. Transformation of experience: toward a new relationship with nature. Conservation Letters http://dx.doi.org/10.1111/conl.12337

Colding, J., and S. Barthel. 2013. The potential of "urban green commons" in the resilience building of cities. Ecological Economics 86:156-166. http://dx.doi.org/10.1016/j.ecolecon.2012.10.016

Corrigan, M. P. 2011. Growing what you eat: developing community gardens in Baltimore, Maryland. Applied Geography 31(4):1232-1241. http://dx.doi.org/10.1016/j.apgeog.2011.01.017 
Crumley, C. 2000. From garden to globe: linking the time and space with meaning and memory. Chapter 7 in R. J. McIntosh, J. A. Tainter, and S. Keech McIntosh, editors. The way the winds blows. Climate, history and human action. Columbia University Press, New York, New York, USA.

D'Abundo, M. L., and A. M. Carden. 2008. "Growing wellness": the possibility of promoting collective wellness through community garden education programs. Community Development 39(4):83-94. http://dx.doi.org/10.1080/15575330809489660

Davies, W. K. D. 2015. Theme cities: solutions for urban problems. Springer, Dordrecht, The Netherlands. http://dx.doi. org/10.1007/978-94-017-9655-2

Demeulenaere, E. 2014. A political ontology of seeds: the transformative frictions of a farmers' movement in Europe. Focal - Journal of Global and Historical Anthropology 69:45-61. http:// dx.doi.org/10.3167/fcl.2014.690104

de Vries, S., S. M. E. van Dillen, P. P. Groenewegen, and P. Spreeuwenberg. 2013. Streetscape greenery and health: stress, social cohesion and physical activity as mediators. Social Science and Medicine 94:26-33. http://dx.doi.org/10.1016/j.socscimed.2013.06.030

Doyle, R., and M. Krasny. 2003. Participatory rural appraisal as an approach to environmental education in urban community gardens. Environmental Education Research 9(1):91-115. http:// dx.doi.org/10.1080/13504620303464

Drake, L., and L. J. Lawson. 2014. Validating verdancy or vacancy? The relationship of community gardens and vacant lands in the U.S. Cities 40:133-142. http://dx.doi.org/10.1016/j. cities.2013.07.008

Ferris, J., C. Norman, and J. Sempik. 2001. People, land and sustainability: community gardens and the social dimension of sustainable development. Social Policy and Administration 35 (5):559-568. http://dx.doi.org/10.1111/1467-9515.t01-1-00253

Folke, C., R. Biggs, A. V. Norström, B. Reyers, and J. Rockström. 2016. Social-ecological resilience and biosphere-based sustainability science. Ecology and Society 21(3): 41. http://dx.doi.org/10.5751/ ES-08748-210341

Folke, C., T. Hahn, P. Olsson, and J. Norberg. 2005. Adaptive governance of social-ecological systems. Annual Review of Environment and Resources 30(1):441-473. http://dx.doi. org/10.1146/annurev.energy.30.050504.144511

Folke, C., and Gunderson, L. 2012. Reconnecting to the biosphere: a social-ecological renaissance. Ecology and Society 17(4):55. http://dx.doi.org/10.5751/ES-05517-170455

Francis, J., B. Giles-Corti, L. Wood, and M. Knuiman. 2012. Creating sense of community: the role of public space. Journal of Environmental Psychology 32(4):401-409. http://dx.doi.org/10.1016/ j.jenvp.2012.07.002

Fuhlendorf, S., D. M. Engle, C. M. O’Meilia, J. R. Weir, and D. C. Cummings. 2009. Does herbicide weed control increase livestock production on non-equilibrium rangeland? Agriculture, Ecosystems and Environment 132:1-6. http://dx.doi.org/https:// doi.org/10.1016/j.agee.2009.02.015
Gaston, K. J., R. M.Smith, K. Thompson, and P. H.Warren. 2005a. Urban domestic gardens (II): experimental tests of methods for increasing biodiversity. Biodiversity and Conservation 14(2):395-413. http://dx.doi.org/https://doi.org/10.1007/s10531-004-6066$\underline{x}$

Gaston, K. J., P. H. Warren, K. Thompson, and R. M. Smith. $2005 b$. Urban domestic gardens (IV): the extent of the resource and its associated features. Biodiversity and Conservation 14:33273349. http://dx.doi.org/https://doi.org/10.1007/s10531-004-9513-9

Goddard, M., A. J. Dougill, and T. G. Benton. 2010. Scaling up from gardens: biodiversity conservation in urban environments. Trends in Ecology and Evolution 25(2):90-98. http://dx.doi. org/10.1016/j.tree.2009.07.016

Graine de Jardins. 2016. Carte des jardins. [online] URL: http:// www.jardinons-ensemble.org/spip.php?rubrique1\#2016-06-01.

Guitart, D., C. Pickering, and J. Byrne. 2012. Past results and future directions in urban community gardens research. Urban Forestry and Urban Greening 11(4):364-373. http://dx.doi. org/10.1016/j.ufug.2012.06.007

Hand, K. L., C. Freeman, P. J. Seddon, M. R. Recio, A. Stein, and Y. van Heezik. 2017. The importance of urban gardens in supporting children's biophilia. Proceedings of the National Academy of Sciences 114(2):274-279. http://dx.doi.org/10.1073/ pnas. 1609588114

Hartig, T., G. W. Evans, L. D. Jamner, D. S. Davis, and T. Gärling. 2003. Tracking restoration in natural and urban field settings. Journal of Environmental Psychology 23(2):109-123. http://dx. doi.org/10.1016/S0272-4944(02)00109-3

Hartig, T., M. Mang, and G. Evans. 1991. Restorative effects of natural environment experiences. Environment and Behavior 23 (1):3-26. http://dx.doi.org/10.1177/0013916591231001

Hartig, T., R. Mitchell, S. de Vries, and H. Frumkin. 2014. Nature and health. Annual Revieuw of Public Health 35:207-228. http:// dx.doi.org/10.1146/annurev-publhealth-032013-182443

Hartig, T., A. E. van den Berg, C. M. Hagerhall, M. Tomalak, N. Bauer, R. Hansmann, A. Ojala, E. Syngollitou, G. Carrus, A. van Herzele, S. Bell, M. T. Camilleri Podesta, and G. Waaseth. 2011. Health benefits of nature experience psychological, social and cultural processes. Forests, Trees and Human Health. Springer. Netherlands. http://dx.doi.org/10.1007/978-90-481-9806-1 5

Harvey, D. 2013. Rebel cities. from the right to the city to the urban revolution. Verso, New York, New York, USA.

Incroyables comestibles Paris. 2016. Facebook Page. [online] URL: https://www.facebook.com/Incroyables-ComestiblesParis-122467857901658/.

Institut national de la statistique et des études économiques (INSEE). 2013. Population en 2013 : Pré-Saint-Gervais (93061), Paris (75) and Montreuil (93048). [online] URL: https://www. insee.fr/fr/statistiques/1405599?geo=COM-93061+DEP-75+COM-93048

Irvine, S., L. Johnson, and K. Peters. 1999. Community gardens and sustainable land use planning: a case-study of the Alex Wilson community garden. Local Environment 4(1):33-46. http://dx.doi. org/10.1080/13549839908725579 
Kadlec, T., J. Benes, V. Jarosik, and M. Konvicka. 2008. Revisiting urban refuges: changes of butterfly and burnet fauna in Prague reserves over three decades. Landscape and Urban Planning 85 (1):1-11. http://dx.doi.org/10.1016/j.landurbplan.2007.07.007

Kaplan, R. 1973. Some psychological benefits of gardening. Environment and Behavior 5(2):145-162. http://dx.doi.org/https:// doi.org/10.1177/001391657300500202

Kaplan, R., and S. Kaplan. 1989. The experience of nature: a psychological perspective. Cambridge University Press, New York, New York, USA.

Kaplan, S. 1995. The restorative benefits of nature: toward an integrative framework. Journal of Environmental Psychology 15:169-182. http://dx.doi.org/10.1016/0272-4944(95)90001-2

Kardan, O., P. Gozdyra, B. Misic, F. Moola, L. J. Palmer, T. Paus, and M. G. Berman. 2015. Neighborhood greenspace and health in a large urban center. Scientific Reports 5(11610). http://dx.doi. org/https://doi.org/10.1038/srep11610

Keniger, L. E., K. J. Gaston, K. N. Irvine, and R. A. Fuller. 2013. What are the benefits of interacting with nature? International Journal of Environmental Research and Public Health 10(3):913935. http://dx.doi.org/https://doi.org/10.3390/ijerph10030913

Kokopelli. 2016. Association Kokopelli_pour la libération de la semence et de l'humus. Newsletter. [online] URL: https:// kokopelli-semences.fr/?lang=fr-fr.

Kowarik, I. 2011. Novel urban ecosystems, biodiversity and conservation. Environmental Pollution 159:1974-1983. http://dx. doi.org/10.1016/j.envpol.2011.02.022

Krasny, M. E., S. R. Crestol, K. G. Tidball, and R. C. Stedman. 2014. New York City's oyster gardeners: memories and meanings as motivations for volunteer environmental stewardship. Landscape and Urban Planning 132:16-25. http://dx.doi. org/10.1016/j.landurbplan.2014.08.003

Krasny, M. E., and R. Doyle. 2002. Participatory approaches to program development and engaging youth in research: the case of an inter-generational urban community gardening program. Journal of Extension 40(5).

Krasny, M. E. and Tidball, K. G. 2012. Civic ecology: a pathway for earth stewardship in cities. Frontiers in Ecology 10(5):267-273. http://dx.doi.org/10.1890/110230

Krishna, A. 2002. Active social capital. Training the roots of development and democracy. Columbia University Press, New York, New York, USA.

Loram, A., P. H. Warren, and K. J. Gaston. 2008. Urban domestic gardens (XIV): the characteristics of gardens in five cities. Environmental Management 42(3):361-376. http://dx.doi.org/10.1007/ s00267-008-9097-3

Maas, J., S. M. E. van Dillen, R. A. Verheij, and P. P. Groenewegen. 2009. Social contacts as a possible mechanism behind the relation between green space and health. Health and Place 15(2):586-595. http://dx.doi.org/10.1016/j.healthplace.2008.09.006

Maas, J., R. A. Verheij, P. P. Groenewegen, S. de Vries, and P. Spreeuwenberg. 2006. Green space, urbanity, and health: how strong is the relation? Journal of Epidemiology and Community
Health 60(7):587-592. http://dx.doi.org/https://doi.org/10.1136/ jech.2005.043125

Mairie de Paris. 2012a. Convention cadre d'occupation et d'usage pour la gestion d'un jardin collectif. [online] URL : https://api-site. paris.fr/images/123237.pdf.

Mairie de Paris. 2012b. La Charte Main Verte des jardins partagés de Paris. [online] URL: http://api-site-cdn.paris.fr/images/123236. pdf.

Maller, C., A. Pryor, and P. Brown. 2005. Healthy nature healthy people: "contact with nature" as an upstream health promotion intervention for populations. Health Promotion International 21 (1):45-54. http://dx.doi.org/10.1093/heapro/dai032

Martínez-Blanco, J., C. Lascano, T. H. Christensen, P. Muñoz, J. Rieradevall, J. Moller, A. Antón, and A. Boldrin. 2013. Compost benefits for agriculture evaluated by life cycle assessment. A review. Agronomy for Sustainable Development 33(4):721-732.

Matteson, K. C., J. S. Ascher, and G. A. Langellotto. 2008. Bee richness and abundance in New York City urban gardens. Annals of the Entomological Society of America 101(1):140-150. http:// dx.doi.org/10.1603/0013-8746(2008)101[140:BRAAIN]2.0.CO:2

Matteson, K. C., and G. A. Langellotto. 2011. Small scale additions of native plants fail to increase beneficial insect richness in urban gardens: native plant additions in urban gardens. Insect Conservation and Diversity 4(2):89-98. http://dx.doi.org/10.1111/ j.1752-4598.2010.00103.X

Mayer, F. S., and C. M. Frantz. 2004. The connectedness to nature scale: a measure of individuals' feeling in community with nature. Journal of Environmental Psychology 24(4):503-515. http://dx. doi.org/10.1016/j.jenvp.2004.10.001

McCracken, D. S., D. A. Allen, and A. J. Gow. 2016. Associations between urban greenspace and health-related quality of life in children. Preventive Medicine Reports 3:211-221. http://dx.doi. org/10.1016/j.pmedr.2016.01.013

Meier, L., and H. Lange. 2009. The new middle classes. Springer, Dordrecht, The Netherlands. http://dx.doi.org/10.1007/978-1-4020-9938-0

Menozzi, M.-J. 2007. Mauvaises herbes, qualité de l'eau et entretien des espaces. Natures Sciences Sociétés 15:144-153. http://dx.doi.org/10.1051/nss:2007041

Misztal, B. A. 2003. Theories of social remembering. Open University Press, Philadelphia, Pennsylvania, USA.

Murdoch, J. 2006. Post-structuralist geography: a guide to relational space. Sage Publications, London, UK.

Ødegaard F., and B. A. Tømmerås. 2000. Compost heapsrefuges and stepping-stones for alien arthropod species in northen Europe. Diversity Distribution 6:45-49. http://dx.doi.org/10.1046/ j.1472-4642.2000.00071.x

Palomino, D., and L. M. Carrascal. 2006. Urban influence on birds at a regional scale: a case study with the avifauna of northern Madrid province. Landscape and Urban Planning 77:276-290. http://dx.doi.org/10.1016/j.landurbplan.2005.04.003

Pergams, O. R. W., and P. A. Zaradic. 2006. Is love of nature in the US becoming love of electronic media? 16-year downtrend in 
national park visits explained by watching movies, playing video games, internet use, and oil prices. Journal of Environmental Management 80(4):387-393. http://dx.doi.org/https://doi.org/10.1016/ j.jenvman.2006.02.001

Pyle, R. M. 1978. The extinction of experience. Horticulture 56:64-67.

Pyle, R. M. 2003. Nature matrix: reconnecting people and nature. Oryx 37(2):206-214. http://dx.doi.org/10.1017/S0030605303000383

Richards, D. R., P. Passy, and R. R. Y. Oh. 2017. Impacts of population density and wealth on the quantity and structure of urban green space in tropical Southeast Asia. Landscape and Urban Planning 157:553-560. http://dx.doi.org/10.1016/j. landurbplan.2016.09.005

Ryan, R. L., R. Kaplan, and R. E. Grese. 2001. Predicting volunteer commitment in environmental stewardship programmes. Journal of Environmental Planning and Management 44(5):629648. http://dx.doi.org/10.1080/09640560120079948

Saldaña, J. 2009. The coding manual for qualitative researchers. Sage Publications, London, UK.

Saldivar-Tanaka, L., and M. E. Krasny. 2004. Culturing community development, neighborhood open space, and civic agriculture: the case of Latino community gardens in New York City. Agriculture And Human Values 21(4):399-412. http://dx.doi. org/10.1023/B:AHUM.0000047207.57128.a5

Schama, S. 1995. Landscape and memory. Vintage Books, New York, New York, USA.

Schmelzkopf, K. 1995. Urban community gardens as contested space. American Geographical Society 85(3):364-381. http://dx. doi.org/10.2307/215279

Serret, H., R. Raymond, J.-C. Foltête, P. Clergeau, L. Simon, and N. Machon. 2014. Potential contributions of green spaces at business sites to the ecological network in an urban agglomeration: the case of Ile-de-France region, France. Landscape and Urban Planning 131:27-35. http://dx.doi. org/10.1016/j.landurbplan.2014.07.003

Shanahan, D. F., R. A. Fuller, R. Bush, B. B. Lin, and K. J. Gaston. 2015. The health benefits of urban nature: how much do we need? BioScience 65(5):476-485. http://dx.doi.org/10.1093/biosci/biv032

Shinew, K. J., T. D. Glover, and D. C. Parry. 2004. Leisure spaces as potential sites for interracial interaction: community gardens in urban areas. Journal of Leisure Research 36(3):336-355.

Soga, M., and K. Gaston. 2016. Extinction of experience: the loss of human-nature interactions. Frontiers in Ecology and the Environment 14(2): 94-101. http://dx.doi.org/10.1002/fee.1225

Soga, M., K. J. Gaston, and Y. Yamaura. 2017. Gardening is beneficial for health: a meta-analysis. Preventive Medicine Reports 5:92-99. http://dx.doi.org/10.1016/j.pmedr.2016.11.007

Somerset, S. M., R. Ball, M. Flett, and R. Geissman. 2005. School-based community gardens: re-establishing healthy relationships with food. Journal of the HEIA 12(2):25-33.

Stedman, R. C. 2002. Toward a social psychology of place. Predicting behavior from place-based cognitions, attitude, and identity. Environment and Behavior 34(5):561-581. http://dx.doi. org/10.1177/0013916502034005001

Stocker, L., and K. Barnett. 1998. The significance and praxis of community-based sustainability projects: community gardens in western Australia. Local Environment 3(2):179-189. http://dx. doi. org/10.1080/13549839808725556

Strauss, A. L. 1987. Qualitative analysis for social scientists. Cambridge University Press, Cambridge, UK. http://dx.doi. org/10.1017/CBO9780511557842

Thomas, K. 1983. Man and the natural world changing attitudes in England 1500-1800. Penguin, London, UK.

Tidball, K., and M. Krasny. 2010a. Stewardship, learning, and memory in disaster resilience. Environmental Education Research 16:591-609. http://dx.doi.org/https://doi.org/10.1080/13504622.$\underline{2010.505437}$

Tidball, K. G., and M. E. Krasny. 2010b. Urban environmental education from a social-ecological perspective: conceptual framework for civic ecology education. Cities and the Environment 3(1): 11. http://dx.doi.org/https://doi.org/10.15365/cate.31112010

Tratalos, J., R. A. Fuller, P. H. Warren, R. G. Davies, and K. J. Gaston. 2007. Urban form, biodiversity potential and ecosystem services. Landscape and Urban Planning 83(4):308-317. http://dx. doi.org/10.1016/j.landurbplan.2007.05.003

Truffaut. 2016. Webpage. [online] URL: http://www.truffaut. com/jardin/plantes-potager/graines-legumes/Pages/produits-graineslegumes.aspx.

Ulrich, R. S. 1979. Visual landscapes and psychological wellbeing. Landscape Research 4(1):17-23.

van Heezik, Y. M., K. J. M. Dickinson, and C. Freeman. 2012. Closing the gap: communicating to change gardening practices in support of native biodiversity in urban private gardens. Ecology and Society 17(1): 34. http://dx.doi.org/10.5751/ES-04712-170134

Wakefield, S., F. Yeudall, C. Taron, J. Reynolds, and A. Skinner. 2007. Growing urban health: community gardening in south-east toronto. Health Promotion International 22(2):92-10. http://dx. doi.org/10.1093/heapro/dam001

White, M. P., I. Alcock, B. W. Wheeler, and M. H. Depledge. 2013. Would you be happier living in a greener urban area? A fixedeffects analysis of panel data. Psychological Science 24(6):920 928. http://dx.doi.org/10.1177/0956797612464659 